\title{
An alternative antimonial schedule to be used in cutaneous leishmaniasis when high doses of antimony are undesirable
}

\author{
Um esquema antimonial alternativo para ser empregado na leishmaniose cutânea \\ quando altas doses de antimônio são indesejáveis
}

\author{
Manoel Paes de Oliveira-Neto ${ }^{1}$ and Marise da Silva Mattos ${ }^{1}$
}

\begin{abstract}
Despite more than half a century of use in leishmaniasis, antimony therapy still presents serious problems concerning dosage and toxicity. Low and high doses have been shown to be equally effective. In this paper, the feasibility of injecting one ampoule of meglumine antimoniate intramuscularly every other day until clinical cure is demonstrated, while studying a series of 40 cutaneous leishmaniasis cases. Total dose used varied from 1,822.5 to 12,150mg of pentavalent antimony and total time of treatment varied from 3 to 10 weeks, with $86 \%$ efficacy. Thirty-six out of the 40 patients are still on follow-up with a mean time of $10.7 \pm 7$ months and a median of 9 months. No relapse or mucosal lesions have been noted so far. The schedule showed good tolerance and easy application and its efficacy was comparable to the officially recommended WHO schedule. Therefore, such a schedule represents a valuable alternative for the cases with high toxicicity to antimony or daily injections are an obstacle to the treatment.
\end{abstract}

Key-words: Cutaneous leishmaniasis. Pentavalent antimony. Low dose. Systemic therapy.

\section{RESUMO}

Apesar de utilizado há mais de meio século no tratamento da leishmaniose, o antimônio apresenta ainda problemas quanto a sua toxicidade e dose ideal. Doses baixas têm se mostrado tão eficazes quanto doses altas. Neste trabalho, apresentamos o resultado do emprego de uma ampola de antimoniato de meglumina intramuscular, em dias alternados, até a cura clínica, numa série de 40 casos. A dose total utilizada, por paciente, variou de 1.822,5 a 12.150mg de antimônio pentavalente e o tempo de tratamento de 3 a 10 semanas com eficácia de 86\%. Dos 40 pacientes estudados, 36 ainda estão em acompanhamento, com um tempo médio de $10,7 \pm 7$ meses e média de 9 meses. Não houve recidivas nem lesões mucosas. O esquema utilizado foi bem tolerado, de fácil aplicação, eficácia comparável ao esquema oficialmente preconizado pela OMS, mostrando-se como valiosa alternativa para os casos com potencial toxicidade ao antimônio ou cuja aplicação de injeções diárias represente um obstáculo ao tratamento.

Palavras-chaves: Leishmaniose cutânea. Antimônio pentavalente. Baixa dose. Tratamento sistêmico.

Ninety-three years ago antimony was used for the first time to treat leishmaniasis (Vianna, 1912) ${ }^{9}$. Since that time numerous therapeutic schedules have been tested, mainly to treat visceral leishmaniasis. The original preparation of emetic tartar was gradually superseded by other compounds such as stibamine glucoside (Neostamf ), para-aminophenyl stibic acid (Neostibosanf ), sodium antimony gluconate (Pentostanf ) and meglumine antimoniate (Glucantimef ). Several schedules have been proposed for the treatment of cutaneous leishmaniasis, all of them based on dosages empirically determined for visceral leishmaniasis. The current recommendation of the World Health Organization is $10-20 \mathrm{mg}$ of pentavalent antimony $\left(\mathrm{Sb}^{\mathrm{v}+}\right)$ per $\mathrm{kg}$ per day for three or four weeks ${ }^{18}$. Nevertheless, for many years in our service at Evandro Chagas Hospital, Oswaldo Cruz Foundation in Rio de Janeiro a regimen of 1 ampoule of meglumine antimoniate, irrespective of body weight, has been used, given by intramuscular injections (IM) for 10 days and repeated three times at 10 day intervals. In a series of patients using this regimen, all of them cured with no mucosal involvement

\footnotetext{
1. Ambulatório de Leishmaniose do Instituto de Pesquisas Clínicas Evandro Chagas da Fundação Oswaldo Cruz, Rio de Janeiro, RJ. Address to: Dra. Marise da Silva Mattos. Rodovia Haroldo Soares Glavan 929, Casa 2, Cacupé, 88050-005 Florianópolis, SC. e-mail: m.s.mattos@ipec.fiocruz.br Recebido para publicação em 19/7/2005 Aceito em 15/5/2006
} 
after 5 years, it was demonstrated that the individual doses according to body weight were highly variable, from 3.8 to $22.3 \mathrm{mg}$ of $\mathrm{Sb}^{\mathrm{V}+} / \mathrm{kg}^{4}$. In other subsequent papers, the effect of a lower dose was studied, $5 \mathrm{mg}$ of $\mathrm{Sb}^{\mathrm{V}+} / \mathrm{kg} /$ day for four weeks, demonstrating the efficacy of such a dose $\mathrm{e}^{56}$. It is also true that the first manufacturer of meglumine antimoniate (Specia), initially recommended a regimen of injections on alternate days up to clinical cure ${ }^{1}$. A scheme of alternate-day injections up to clinical cure was used by one of the authors, with good results, in the Dermatology Clinic of Policlínica Geral do Rio de Janeiro some 37 years ago (MP Oliveira-Neto: unpublished data). Based on that previous successful experience, we decided to try a regimen of IM injections on alternate days again and show the results of a series of cutaneous leishmaniasis cases treated in Rio de Janeiro at the present time.

\section{PATIENTS AND METHODS}

Forty patients who attended our service (the out-patients unit of the Institute of Clinical Research, Oswaldo Cruz Foundation, Rio de Janeiro, Brazil) were enrolled for the study. No distinction was made between gender or age. All the patients were inhabitants of Rio de Janeiro State, presented cutaneous ulcers and presented parasitologically confirmed cutaneous leishmaniasis. They were all submitted to the routine procedures of parasitological diagnosis: biopsy, in-prints, histopathological examination, culture in appropriate media and the detection of parasite DNA by polymerase chain reaction (PCR). The inclusion criterion was diagnostic confirmation by at least one of the above mentioned methods. An exception was made for two children and one elderly person with a clinical-epidemiological diagnosis supported by a positive intradermal leishmanin test. The exclusion criterion was the presence of associated mucosal disease. Routine laboratory tests and an electrocardiogram were performed before treatment in all patients.

All patients, with the exception of one infant, received one ampoule of meglumine antimoniate IM applied on alternate days, Mondays, Wednesdays and Fridays (weekend free), irrespective of body weight, up to clinical cure. The criteria used for drug withdrawal were the complete epithelization of the ulcers and absence of any erythematous scarring. Glucantimef in $5 \mathrm{ml}$ ampoules containing $405 \mathrm{mg}$ of $\mathrm{Sb}^{5+}$ was used for treatment.

Follow-up. Follow-up was scheduled for six visits during a 2-year observation period: first, up on drug withdrawal and at one month, three months, six months, one year and two years later.

\section{RESULTS}

Of the 40 patients enrolled in the study, 23 were males and 17 females. Age varied from 2 (youngest) to 78 years old (oldest), with a median of 39 years old. The mean number of lesions was $3.4 \pm 11.1$. This high standard deviation was due to one patient presenting 70 lesions. Upper and lower extremities were affected in more than half the cases (32). Up to now 36 of the 40 patients are still on follow-up. Four patients were excluded because two of them did not return and the other two failed to take the medication. The mean time of follow-up was $10.7 \pm 7$ months with a median of 9 months.

The overall clinical response to the therapy used was very good. Thirty-one $(86.1 \%)$ patients $(31 / 36)$ showed complete healing of the lesions up on drug withdrawal and have shown no relapse during the observation period (Figures 1 to 3 ). The adhesion of patients to the treatment was completely satisfactory.

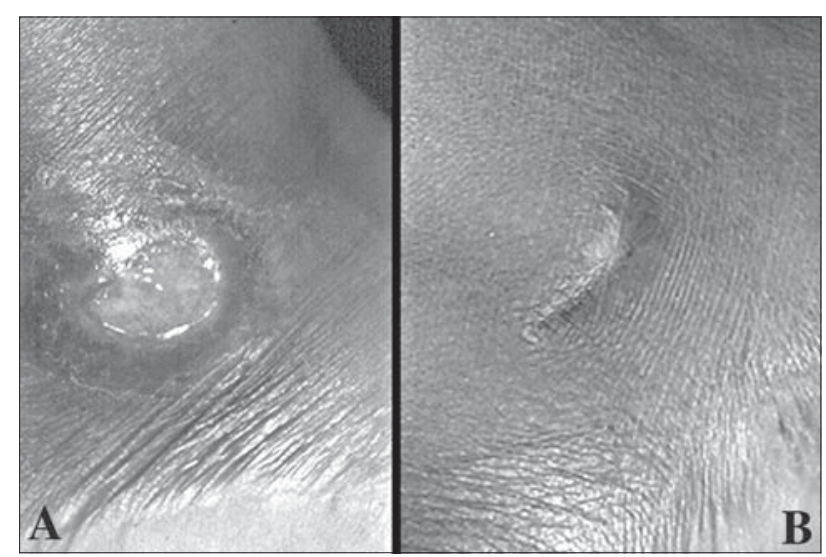

Figure 1 - A: Active lesion. Patient healed after 4 weeks of therapy; B: Two years after cure.

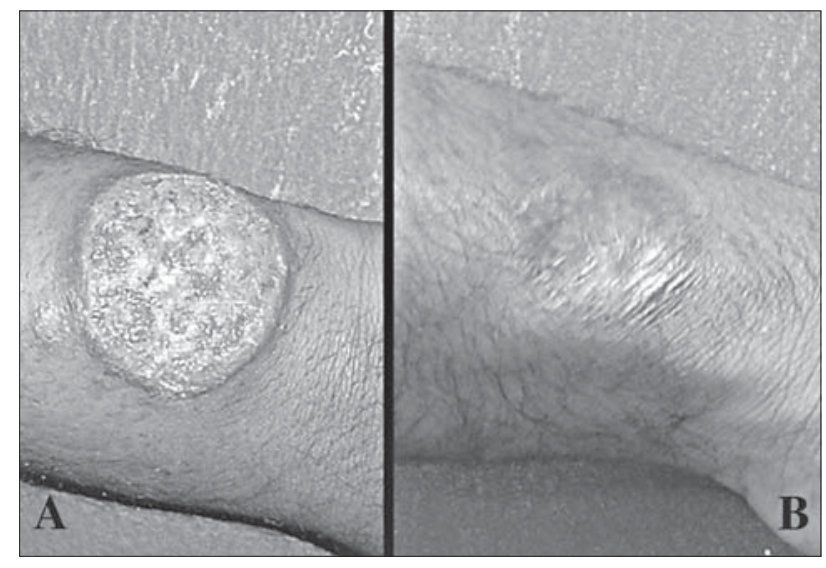

Figure 2 - A: Active lesion. Patient healed after 7 weeks of therapy; B: Six months after cure.

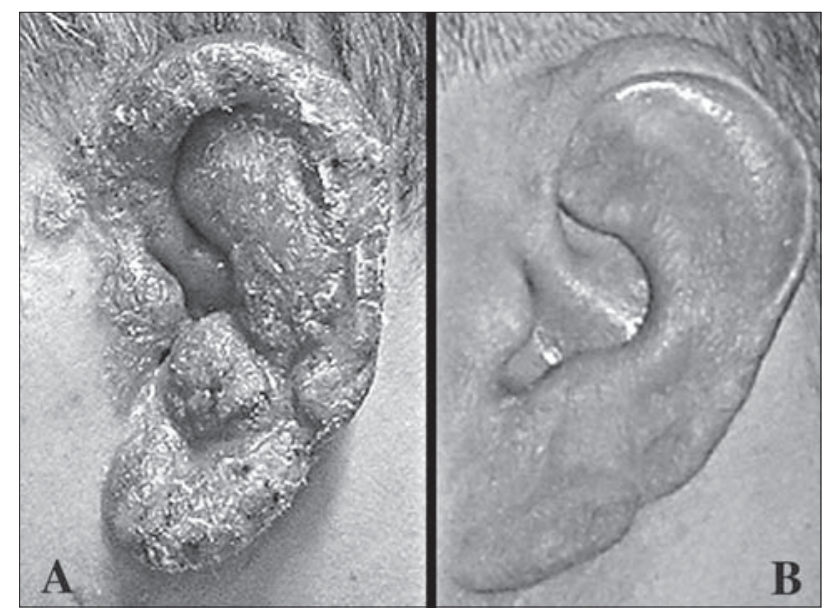

Figure 3 - A: Active lesion. Patient healed after 10 weeks of therapy; B: Six months after cure. 
Minor side effects, mainly pain at the injection sites, light arthralgias and/or nausea, were registered in six patients. Five $(13.8 \%)$ patients (5/36) failed; two (5.5\%) (2/36) of these 5 patients, who showed no sign of improvement after six weeks of treatment, were retreated with a dose of $15 \mathrm{mg} \mathrm{Sb}^{5+}$ / $\mathrm{kg} /$ day for 21 days, with good response, indicating that the use of a prior low dose did not induce $\mathrm{Sb}^{5+}$ resistance. Another two $(5.5 \%)$ patients $(2 / 36)$ presented relapse after an apparent cure and were retreated with the same schedule with good results; and one $(2.7 \%)$ patient $(1 / 36)$ who still presented inflammatory papules at the end of two months of treatment, was retreated with intralesional therapy, three intralesional applications at 15 day intervals, with complete remission of the lesions.

Since as many ampoules as necessary were used to reach epithelization, the number of ampoules and, consequently, the time interval required to obtain cure were variable. The lowest number of ampoules used to obtain cure was nine, corresponding to 3 weeks of therapy, and the highest number was 30 ampoules, or 10 weeks of therapy, with a mean of 6.2 weeks of therapy. The lowest total dose of antimony used was $1,822.5 \mathrm{mg}$, for a patient weighing $14 \mathrm{~kg}$ (30.86 pounds), who used only half an ampoule 3 times a week, for 3 weeks, and the highest dose was $12,150 \mathrm{mg}$, in a patient weighing $78 \mathrm{~kg}$ (171.96 pounds), who used one ampoule 3 times a week for 10 weeks. Table 1 shows the extremes of total antimony used compared to the expected conventional therapy of $20 \mathrm{mg}$ of $\mathrm{Sb}^{5+} / \mathrm{kg} /$ dia regimen for three weeks. The economic advantage varied from $\mathrm{R} \$ 35.00$ for the shortest treatment to $\mathrm{R} \$ 135.00$ for the longest ( $\mathrm{R} \$ 3.50 /$ ampoule).

Table 1 - Total $S b^{V+}$ dose of the alternative schedule compared with that employed in the conventional schedule.

\begin{tabular}{|c|c|c|c|c|c|}
\hline $\begin{array}{l}\text { Total Sb } \\
\text { used }\end{array}$ & & $\begin{array}{c}\text { Ampoules } \\
\left(\mathrm{n}^{\mathrm{o}}\right)\end{array}$ & $\begin{array}{c}\mathrm{Sb}^{\mathrm{V}+} / \mathrm{kg} / \text { day } \\
(\mathrm{mg})\end{array}$ & $\begin{array}{l}\text { Duration } \\
\text { of treatment } \\
\text { (weeks) }\end{array}$ & $\begin{array}{l}T_{0 t a l} \mathrm{Sb}^{\mathrm{V}+} \text { for } \\
\text { conventional } \\
\text { therapy }(\mathrm{mg})\end{array}$ \\
\hline Minimum & $1,822.5 \mathrm{mg}$ & 4.5 & 14.5 & 3 & 5,880 \\
\hline Maximum & $12,150.0 \mathrm{mg}$ & 30.0 & 5.2 & 10 & 32,760 \\
\hline
\end{tabular}

$\mathrm{Sb}^{\mathrm{V}+}$ : pentavalente antomony

\section{DISCUSSION}

The possibility of treating cutaneous leishmaniasis with low doses of antimony has been explored in Rio de Janeiro since $1990^{4567}$. The present schedule represents a true and solid possibility of dealing with the challenges presented by antimonial therapy. Some advantages brought about by the reduced number of ampoules can be promptly noted, such as the economic gain, which is not negligible for developing countries. The other advantages cannot be directly measured, such as the ease of administration and the achievement of patient comfort, for those who received only three injections per week with a rest period on weekends. Such a scheme could be an alternative to the regimen of high doses applied every day for three to four weeks. The current officially recommended regimen is often very difficult to apply in many regions of Brazil, including Rio de Janeiro State, where appropriate primary health care centers are frequently located far away from patients' residences; making the daily journey to receive attendance becomes a heavy burden for the patients. In the case of intravenous application the difficulties are even greater, because many primary health centers refuse to perform this kind of treatment and patients must travel long distances to the nearest general hospital. Furthermore, the side effects are minimal; only six patients presented slight arthralgias, nausea or pain at the injection sites. In contrast, one of the patients who did not achieve cure was submitted to the conventional high dose therapy and had to be hospitalized to treat severe arthralgias. It was noticeable that cure was achieved with a much smaller dose than that recommended by the WHO, at least in Rio de Janeiro State $^{8}$. It also seems evident that this goal was achieved due to the prolongation of the administration period. We believe that this could be the main disadvantage related to this schedule. However, the large reduction in the occurrence of side effects added to the practicality of the schedule, thus showing a good cost-benefit relation. This raises the question as to why time cannot be used as a co-adjuvant to therapy. Most intracellular pathogens are treated with long term therapy, such as Trypanosoma cruzi, Mycobacterium tuberculosis, Mycobacterium leprae, Paracoccidiodes brasiliensis, but Leishmania is not. It is also known that spontaneous healing of leishmaniasis is related to the long evolution of the disease. It was recently demonstrated that time can act as a positive independent factor for cure during antimonial therapy ${ }^{3}$. Indeed, host-parasite relationship must be better understood in order to explain the mechanisms related to the molecular, intra-cellular and immunological controls of Leishmania over time. When all the patients in this series reach the two year observation period, we will know the incidence of relapse and a new communication will be published. Based on current experience, however, it is highly improbable that a significant number of patients will develop relapse or mucosal lesions. This schedule has shown that good results can be achieved without the use of high doses, like those suggested by the WHO, and our service has demonstrated that such an alternative schedule is feasible. This schedule could be an effective choice in patients for whom a less aggressive antimony therapy is desirable. The practice of clinical medicine has taught us that the prescription of a drug should be customized for each sick individual and their particular epidemiological and familial history. Thus, the proposed schedule should be tried, without recrimination, whenever antimony toxicity is undesirable or predictable.

\section{ACKNOWLEDGEMENTS}

The authors would like to thank Mary Lucy Ribeiro Pinto for her valuable help with the illustrations.

\section{REFERENCES}

1. Chulay JD, Oster CN, McGreevy PB, Hendricks LD, Kreutzer RD. Pharmakokinetics of antimony during treatment of visceral leishmaniasis with sodium stibogluconate or meglumine antimoniate. Transactions of the Royal Society of Tropical Medicine and Hygiene 82:69-72, 1988.

2. Fundação Nacional de Saúde. Manual de Controle da Leishmaniose Tegumentar Americana. Ministério da Saúde, Brasília, p.29, 2000. 
3. Mattos M. Determinação de parâmetros clínicos e prognósticos para o controle de cura da leishmaniose tegumentar americana. Thesis. Oswaldo Cruz Foundation, Rio de Janeiro, 2004.

4. Oliveira-Neto MP, Schubach A, Araujos ML, Pirmez C. High and low doses of antimony $\left(\mathrm{Sb}^{v}\right)$ in American cutaneous leishmaniasis. A five-year follow-up study of 15 patients. Memórias do Instituto Oswaldo Cruz 91:207-209, 1996.

5. Oliveira-Neto MP, Schubach A, Mattos M, Gonçalves-Costa SC, Pirmez C. A low dose antimony treatment in 159 patients with American cutaneous leishmaniasis: extensive follow-up studies (up to 10 years). American Journal of Tropical Medicine and Hygiene 57:651-655, 1997.

6. Oliveira-Neto MP, Schubach A, Mattos M, Gonçalves-Costa SC, Pirmez C. Treatment of American cutaneous leishmaniasis: a comparison between low dosage $(5 \mathrm{mg} / \mathrm{kg} /$ day $)$ and high dosage $(20 \mathrm{mg} / \mathrm{kg} /$ day $)$ antimony regimens. Pathologie Biologie 45:496-499, 1997.
7. Oliveira-Neto MP, Schubach A, Mattos M, Gonçalves-Costa SC, Pirmez C. Intralesional therapy of American cutaneous leishmaniasis with pentavalent antimony in Rio de Janeiro, Brazil - an area of Leishmania (Viannia) braziliensis transmission. International Journal of Dermatology 36:463-468, 1997.

8. Schubach A0, Marzochi KB, Moreira JS, Schubach TM, Araújo ML, Vale AC. Retrospective study of 151 patients with cutaneous leishmaniasis treated with meglumine antimoniate. Revista da Sociedade Brasileira de Medicina Tropical 38: 213-217, 2005.

9. Vianna G. Comunicado à Sessão de 24 de abril de 1912 da Sociedade Brasileira de Dermatologia. Boletim da Sociedade Brasileira de Dermatologia 1:36-38, 1912.

10. World Health Organization. The leishmaniasis. Technical report series 793:59-62, 1990 